Japan. J. Med. Sci. Biol., 33, 185-188, 1980

Report

\title{
DRUG RESISTANCE OF ESCHERICHIA COLI STRAINS ISOLATED FROM CHICKEN
}

\author{
Акıко SATO, Kiyoshi TAGAWA*, Yasuyoshi IKE** \\ and SUSUMU MITSUHASHI**
}

\begin{abstract}
Niigata Women's College, Ebigase, Niigata 950, *Department of Agriculture, Kagawa University, Miki-cho, Kagawa 761-07, and **Department of Microbiology, School of Medicine Gunma University, Maebashi, Gunma 371
\end{abstract}

(Received, February 15, 1980. Accepted, March 28, 1980)

Two hundred and eighty-seven drug-resistant strains of Escherichia coli were isolated from 150 ground meat samples of chicken purchased at markets in 1978, and $210 \mathrm{R}$ plasmids were demonstrated in those strains.

The most frequent resistance pattern $(88 \%)$ included SA or TC resistance. The pattern associated with SM resistance was secondly frequent and the frequency of CM resistance was as low as $20 \%$. In relation to TC, CM, SM, and SA, the isolation frequency was the highest with strains triple resistant to any combination of three of four drugs. Among the resistant $E$ coli strains, $\mathrm{R}$ plasmids with single resistance to each of four drugs and those accompanying KM or APC resistance were most frequently demonstrated.

The use of antibiotics has brought many advantages to the livestock industry. The drugs not only cure the animals of bacterial infections but also accelerate growth and the increase in the body size. However, long-term administration of antibiotics has brought an increase in the number of drug-resistant organisms, especially those with conjugally transferable resistance. This paper deals with the studies on the distribution of drug resistance plasmids among $E$. coli strains isolated from chickens purchased at commercial markets.

We isolated $287 \mathrm{E}$. coli strains resistant to any one or any combination of the drugs tested, i.e., TC, CM, SM, SA, KM and APC. Drug-resistant E. coli strains were isolated from all chicken materials tested. SA- and TC-resistant strains were isolated most frequently $(87.8 \%$ and $87.5 \%$, respectively), followed by SM- $(68.6 \%)$ and KM-resistant ones $(41.8 \%)$. The isolation frequencies of CM- and APC-resistant strains were very low, being $22.0 \%$ and $22.3 \%$, respectively.

佐藤昭子（新潟県立女子短期大学 新潟市海老ヶ瀬 471)

田河 清 (香川大学農学部 香川県高松市)

池 康嘉 - 三橋 進（群馬大学医学部 前橋市昭和町 3-39-22) 
TABLE 1

Resistance patterns of $\mathrm{E}$. coli strains isolated from chicken

\begin{tabular}{|c|c|c|c|c|c|}
\hline \multicolumn{2}{|c|}{ Rasistance patterns ${ }^{a}$} & \multicolumn{2}{|c|}{ Isolation frequency $(\%)$} & \multicolumn{2}{|c|}{ Number of $\mathrm{R}^{+}$strains $(\%)$} \\
\hline Quadruple & TC. CM.SM.SA & .51 & $(17.8)$ & 33 & $(64.7)$ \\
\hline \multirow[t]{4}{*}{ Triple } & TC.SM.SA & $111(38.7)$ & & 64 & \\
\hline & TC. CM. SA & $7(2.4)$ & $(42.5)$ & 6 & $73(59.8)$ \\
\hline & TC. CM.SM & $1(0.4)$ & & 1 & \\
\hline & CM.SM.SA & $3(1.0)$ & & 2 & \\
\hline \multirow[t]{3}{*}{ Double } & TG.SA & $49(17.1)$ & & 20 & \\
\hline & TC.SM & $17(5.9)$ & $(27.5)$ & 11 & $35(44.3)$ \\
\hline & SM.SA & $13(4.5)$ & & 4 & \\
\hline \multirow[t]{4}{*}{ Single } & SA & $18(6.2)$ & & 4 & \\
\hline & TC & $15(5.2)$ & $(12.2)$ & 4 & $10(28.6)$ \\
\hline & CM & $1(0.4)$ & & 1 & \\
\hline & SM & $1(0.4)$ & & 1 & \\
\hline \multicolumn{2}{|c|}{ Total number of strains } & 287 & & 151 & $(52.6)$ \\
\hline
\end{tabular}

a In relation to resistance to $\mathrm{TC}, \mathrm{CM}, \mathrm{SM}$ and SA.

One hundred and fifty ground meat samples of chicken were purchased from 100 meatshops in Niigata and Takamatsu cities in 1978. Fifty Esherichia coli strains were isolated from each sample and drug resistance of these strains was determined by the replica plating method using the heart infusion (HI) agar plate containing each of the drugs, $\mathrm{i}$. e., tetracycline (TC, $12.5 \mu \mathrm{g} / \mathrm{ml}$ ), chloramphenicol (CM, $12.5 \mu \mathrm{g} / \mathrm{ml}$ ), streptomycin (SM, $12.5 \mu \mathrm{g} / \mathrm{ml}$ ), kanamycin (KM, $25.0 \mu \mathrm{g} / \mathrm{ml}$ ) and ampicillin (APC, $25.0 \mu \mathrm{g} / \mathrm{ml}$ ). A semisynthetic medium (Devis et al., 1950) was used for the determination of SA resistance; the criteria for resistance was $100 \mu \mathrm{g} / \mathrm{ml}$ of SA. One $E$. coli strain was picked from the strains carrying the same resistance pattern isolated from each meat sample. Thus, total of 287 drug-resistant $E$. coli strains was collected.

\section{TABLE II}

Demonstration frequency of $K M$ - and $A P C$-resistant E. coli strains in relation to resistance to $T C, C M, S M$ and $S A$

\begin{tabular}{lccc}
\hline \multirow{2}{*}{$\begin{array}{c}\text { Resistance } \\
\text { patterns }\end{array}$} & $\begin{array}{c}\text { Number of } \\
\text { strains }\end{array}$ & \multicolumn{2}{c}{ Number of strains resistant to (\%) } \\
\cline { 3 - 4 } & & KM & APC \\
\hline Quadruple & 51 & $25(49.0)$ & $17(33.3)$ \\
Triple & 122 & $59(48.4)$ & $33(27.0)$ \\
$\begin{array}{l}\text { Double } \\
\text { Single }\end{array}$ & 79 & $31(39.2)$ & $13(16.5)$ \\
& 35 & $5(14.3)$ & $1(2.9)$ \\
\hline $\begin{array}{l}\text { Total number } \\
\text { of strains }\end{array}$ & 287 & $120(41.8)$ & $64(22.3)$ \\
\hline
\end{tabular}

a In relation to resistance to $\mathrm{TC}, \mathrm{CM}, \mathrm{SM}$ and $\mathrm{SA}$.

Resistance patterns of $E$. coli strains to TC, CM, SM and SA are shown in Table I. Triply resistant strains were isolated most frequently $(42.5 \%)$, followed by doubly, quadruply and singly resistant ones. Among triply resistant strains, (TC.SM.SA)-resistant ones were most frequently seen. 
Demonstration frequencies of KM- and APC-resistant strains in relation to the resistance to $\mathrm{TC}, \mathrm{CM}, \mathrm{SM}$ and $\mathrm{SA}$ are shown in Table II. KM-resistant strains were demonstrated most frequently among quadruply and triply resistant ones (about 49\%), followed by doubly and singly resistant ones, indicating that KM-resistance was demonstrated among the strains carrying multiple resistance.

TABLE III

Resistance patterns of $R$ plasmids

\begin{tabular}{|c|c|c|}
\hline \multirow{2}{*}{$\begin{array}{l}\text { Resistance patterns } \\
\text { TC. CM.SM.SA }\end{array}$} & \multicolumn{2}{|c|}{ Number of plasmids (\%) } \\
\hline & 17 & $(8,1)$ \\
\hline TC.SM.SA & 10 & \\
\hline CM. SM.SA & 3 & \\
\hline TC. CM. SM & 1 & \\
\hline TC.SM.SA.KM & 3 & $22(10.5)$ \\
\hline TC.CM. SA. APC & 2 & \\
\hline TC.SM. SA. APC & 1 & \\
\hline TC. SM. SA. KM. APC & 2 & \\
\hline SM. SA & 16 & \\
\hline TC.SM & 14 & \\
\hline TC. SA & 5 & \\
\hline CM.SA & 1 & \\
\hline SM. SA. KM & 8 & \\
\hline TC. SM. KM & 6 & \\
\hline TC.SA. KM & 3 & $70(33.3)$ \\
\hline SM. SA. APC & 2 & \\
\hline TC. SM. APG & 2 & \\
\hline TC. CM. APG & 1 & \\
\hline SM. SA. KM. APC & 6 & \\
\hline TC. SA. KM. APC & 3 & \\
\hline TC. SM. KM. APC & 2 & \\
\hline CM. SA. KM. APC & 1 & \\
\hline SA & 21 & \\
\hline KM & 16 & \\
\hline TC & 11 & \\
\hline CM & 4 & \\
\hline SM & 4 & \\
\hline SM. KM & 14 & \\
\hline SA, KM & 10 & $101(48.1)$ \\
\hline TC. KM & 2 & \\
\hline TC. APG & 1 & \\
\hline KM. APC & 3 & \\
\hline TC. KM. APC & 5 & \\
\hline SM. KM. APC & 7 & \\
\hline CM. KM. APC & 3 & \\
\hline
\end{tabular}

Two substarains of $E$. coli $\mathrm{K} 12 \mathrm{ML1410}$ (met nal $\mathrm{F}^{-}$) (nalre, resistant to nalidixic acid) and $E$. coli $\mathbf{W} 3630$ were used as the recipients of $\mathbf{R}$ plasmid transfer. Conjugal transfer of drug resistance was performed by the method reported previously (Tanaka et al., 1969). 
Demonstration frequencies of APC-resistant strains in relation to the aforementioned four drugs were similar to those carrying KM-resistance. KM- and APC-resistant strains were frequently demonstrated among multiple-resistant ones compared with singly resistant ones in relation to resistance to $\mathrm{TC}, \mathrm{CM}, \mathrm{SM}$ and SA.

R plasmids carrying KM-resistance were isolated from 71 strains among 120 KM-resistant ones (59.2\%). Of 64 APG-resistant strains, 31 (48.4\%) carried $\mathrm{R}$ plasmids encoding APC-resistance.

We isolated $210 \mathrm{R}$ plasmids $(73 \%)$ from 287 drug-resistant $E$. coli strains. Resistance patterns of $\mathbf{R}$ plasmids are shown in Table III. $\mathbf{R}$ plasmids carrying single resistance to TC, CM, SM or SA or those accompanying KM or APC resistance were isolated most frequently $(48.1 \%$ ), followed by those encoding double, triple and quadruple resistance to one and any combination of two or three of TC, CM, SM and SA in that order. $\mathrm{R}$ plasmids encoding resistance to KM, APC or (KM.APC) were also isolated at high frequencies accompanying triple and double resistance to any combination of two and three of TC, CM, $\mathrm{SM}$ and SA. It should be noted that $\mathbf{R}$ plasmids with single resistance were most frequently demonstrated with the isolates from chicken compared with those of clinical isolates from human beings (Mitsuhashi, 1977).

The $\mathbf{R}$ plasmids showed other distinct resistance patterns compared with those of E. coli or Shigella isolated from human being (Tanaka, Tsunoda and Mitsuhashi, 1969, 1973; Tanaka et al., 1974). The results described in this article show the contamination of chicken meat with drug-resistant $E$. coli strains probably from fowls. From these resistant $E$. coli strains, R plasmids were isolated at high frequencies, suggesting a high frequency of $\mathbf{R}$ plasmid transfer from fowl to fowl on farms. The high contamination rate of chicken meat with $E$. coli strains carrying $\mathrm{R}$ plasmids tells us the necessity for taking public health precaution in animal husbandry.

\section{ACKNOWLEDGEMENT}

This work was supported in part by a research grant (No. 211912, 311201 and 410701) from the Ministry of Education, Science and Culture, Japan.

\section{REFERENCES}

Devis, B. D. ANd Mingioli, E. S. (1950): Mutants of Escherichia requiring methionine or vitamin $\mathrm{B}_{12}$. J. Bacteriol., 60, 17-28.

Mitsuhashi, S. (1977): Epidemiology of $\mathrm{R}$ factors. p. 25-48. In S. Mitsuhashi [ed.], R. factor, University of Tokyo Press, Tokyo.

Tanaka, T., Tsunoda, M. And Mrtsuhashi, S. (1969): Distribution of R factor among Shigella strains isolated in Japan. Japan. J. Microbiol., 13, 187-191.

Tanaka, T., Tsunoda, M. And Mrtsuhashi, S. (1973): Distribution of $\mathrm{R}$ factors among Shigella strains isolated in Japan (II). Japan. J. Microbiol., 17, 291-295.

Tanaka, T., Kobayashi, A., Ikemura, K., Hashimoto, H. and Mitsuhashi, S. (1974): Drug resistance and distribution of $\mathrm{R}$ factors among $E$. coli strains. Japan. J. Microbiol., 18, 343-347. 